\title{
CHROMOSOME NUMBERS AND RELATIONSHIPS IN THE GENUS ATRICHUM IN NORTH AMERICA ${ }^{1}$
}

\author{
Robert J. Lowry
}

Frye (1937) included in the genus Atrichum in North America the following taxa: $A$. crispum (James) Sull., A. crispum var. molle (Holz.) Frye; A. undulatum (Hedw.) Beauv., A. undulatum var. haussknechtii (Jur. and Milde) Frye, A. undulatum var. selwyni (Aust.) Frye, $A$. undulatum var. minus (Lam. and DC.) Web. and Mohr; A. angustatum (Brid.) B.S.G., $A$. angustatum var. plurilamellatum (Jenn.) Frye; $A$. papillosum (Jenn.) Frye; and $A$. macmillani (Holz.) Frye. The genus is a difficult one to interpret taxonomically since many of the morphological features vary only quantitatively. Frye's comments concerning several of the above species and varieties illustrate the point. Of $A$. undulatum var. minus he says, "This seems to be merely a depauperate condition of the plants. However, there is an element of uncertainty and thus it seems best to keep it separate." Of $A$. angustatum var. plurilamellatum he says, "Papillose plants of this should be referred to $A$. papillosum. Possibly those not papillose should be referred to $A$. angustatum, but until we know more about the range and limits of variation it seems best to keep it distinct as a variety." of $A$. papillosum and $A$. macmillani he says, "The two are about equally papillose. Perhaps $A$. macmillani is merely a depauperate form of $A$. papillosum, but the collections of both are too limited to enable one to reach a conclusion. For that reason they are kept separate."

Since 1937 more material has become available for study and re-evaluations of several of the above taxa have been published. Anderson (1938) redescribed $A$. macmillani and reduced $A$. papillosum to synonomy with it as the result of a study of 35 specimens of $A$. macmillani from North Carolina. He also found that the differences between $A$. angustatum and $A$. macmillani were reduced to a single character, viz., the papillosity of the leaf cells of the latter. After pointing out that $A$. angustatum in Europe never exhibits papillosity, quoting Dixon, Mönkemeyer and Limpricht, Anderson states that A. macmillani should be retained as a separate species for the following reason: "Papillosity must, then, represent a character which has recently appeared in plants of this continent and in a genus such as this must be allowed a very considerable importance. It seems advisable, therefore, to retain A. macmillani, ....." The discovery by Frye (1949a) that the type specimen of $A$. xantho. pelma (described by C. Müller in 1873; included as a synonym of $A$. angustatum in the Moss Flora of North America by Frye) is papillose made it necessary for him to change the name of plants previ-

1 Received for publication November 18, 1953. ously referred to $A$. macmillani to $A$. xanthopelma (C. Müll.) Jaeg. for reasons of priority. In addition, Frye says the following concerning the relationship between $A$. xanthopelma and $A$. angustatum, " $A$. xanthopelma is not a strong species since it grades into the nonpapillose $A$. angustatum. There would be no violence in considering it a mere variety since the amount of papillosity varies greatly and sometimes is doubtfully present." Apparently the papillose form is much more common than previously supposed. This was pointed out by Schornherst (1950) for plants collected in Florida and southern Georgia where she found that almost every collection exhibited some degree of papillos. ity, if a sufficient number of leaf sections were studied. I have also found this to be true of collections in southern Michigan. It is very difficult to find plants which can, with certainty, be described as nonpapillose.

In 1937, Frye reduced $A$. selwyni to the status of a variety of $A$. undulatum on the grounds that it differs from the species only in the height of the lamellae of the leaf, 6-13 cells high in $A$. selwyni and 2-6 cells high in $A$. undulatum. A re-examination of western material of $A$. selwyni by Frye (1949b) resulted in the discovery that the plant is dioicous and he redescribed the western material as $A$. selwyni. The eastern bisexual material with higher lamellae should now be referred to $A$. undulatum var. altecristatum Ren. and Card. according to Frye. Frye says, "The variety is not clearly distinct and there would be no particular violence in modifying the description of $A$. undulatum to in clude it."

Wareham (1946) described a new species from a specimen collected by Lepage at Rupert River, Quebec, Canada and named it Atrichum paraphylllium. It differs from other Atrichums in possessing paraphyllia on the stems. In other vegetative characters it most closely approaches $A$. undulatum. The specimen was sterile and Wareham was therefore unable to describe the sporophytic characteristics.

To summarize, the genus Atrichum in North America is now interpreted as follows: $A$. crispum (James) Sull., A crispum var. molle (Holz.) Frye; A. undulatum (Hedw.) Beauv., A. undulatum var. haussknechtii (Jur. and Milde) Frye, A. undulatum var. altecristatum Ren. and Card., A. undulatum var. minus (Lam. and DC.) Web. and Mohr; $A$. paraphyllium Wareham; A. selwyni Aust.; A. angustatum (Brid.) B.S.G., A. angustatum var. plurilamellatum (Jenn.) Frye; and $A$. xanthopelma (C. Müll.) Jaeg.

From the above brief taxonomic history, it appears that the genus in North America is composed 
of three major groups: I. A. crispum; II. $A$. undulatum, $A$. selwyni and $A$. paraphyllium; III. $A$. angustatum and the papillose $A$. xanthopelma. The present study was undertaken with the hope that a cytological examination of the genus would contribute to an understanding of the relationships between these groups.

The author extends his thanks to those who have generously contributed living plants and have otherwise facilitated the completion of this study. I would especially like to mention Dr. Ruth $O$. Schornherst Breen, Dr. A. J. Sharp, Dr. L. E. Anderson and Dr. W. C. Steere. The author is also indebted to the University of Michigan Faculty Research Fund and the Fund for the Advancement of Education.

MATERIAL AND METHODS.-In addition to material collected by the author in southern Michigan, the following collections were examined: Atrichum crispum and $A$. undulatum, collected in the vicinity of Alum Cave, Great Smoky Mountains National Park, Tennessee, by Sharp. An interesting collection of this latter species was obtained from $\mathrm{Au}$ Train Falls in northern Michigan by Steere; Atrichum angustatum, collected by Sharp at Knoxville, Tennessee, and Atrichum xanthopelma, collected in Florida by Breen.

Squash preparations were used exclusively in this study. Gametophytic chromosomes were obtained from the tissue of the stem tip and embryonic leaves. The spore mother cells of Atrichum contain a large amount of highly refractive granular material which seriously interferes with the observation of the chromosomes. It was found that most of this material could be eliminated by placing the tissue in acetic alcohol for one to two hours before squashing. Either acetic orcein or acetic carmine was used for staining, depending upon which solution gave the best results with a particular lot of material. The temporary squashes of both gametophytic tissue and spore mother cells were examined and figures were drawn or photographed within the first few days after their completion. The conversion of temporary slides to permanent preparations was not attempted since the loss of useful cells, not abundant at best, was so great that it was impractical. A more detailed account of the technics has been published (Lowry, 1948).

REsults.-For comparative purposes, a short description of each of the species studied, listing only the more important gametophytic characteristics, geographical distribution and cytological data, is presented. For complete descriptions of the species and varieties, the reader is referred to Frye (1937, 1949a, b) and Anderson (1938).

Atrichum crispum (James) Sull. The stem: up to $5 \mathrm{~cm}$. in height, simple, from a branched rhizomelike base. Upper leaves: oval to oblong or lanceolate-oblong, usually less than $5 \mathrm{~mm}$. long, approximately $1 \mathrm{~mm}$. wide; mostly smooth or occasionally slightly undulate; lamina not toothed on the back; apex obtusely acuminate often cuspidate; margin serrate in upper $2 / 3$ to $1 / 2$, teeth mostly single but a few double; leaf cells $20-25 \mu$ in longest diameter; costa with its lamellae obscuring approximately $1 / 10$ of the median leaf width; lamellae $0-4$ frequently interrupted; $1-3$ cells high. Sex: unisexual. Spores: $16-20 \mu$ in diameter. Vermont, New York, Ontario south in the mountains and in the coastal plain to Florida; Oregon, British Columbia; British Isles. The collection reported on in this paper was obtained from Tennessee. The plants were not fruiting and no data regarding the meiotic divisions were obtained. The gametophytic chromosome complement consists of seven chromosomes, four relatively long $(4.2-6.2 \mu)$ and three short $(2.5-$ $3.4 \mu$ ) ; fig. $3-4$.

Atrichum angustatum (Brid.) B.S.G. The stem: up to $5 \mathrm{~cm}$. in height, rarely branched. Upper leaves: linear lanceolate, approximately $4.5 \mathrm{~mm}$. long, $0.6-0.75 \mathrm{~mm}$. wide; undulate; teeth on the back on the undulations; apex acute, cuspidate; margin serrate in upper $1 / 2$ to $1 / 3$, a few or most of the teeth double; leaf cells $10-15 \mu$ in longest diameter; costa wih its lamellae obscuring $1 / 4^{-1 / 3}$ of the median leaf width; lamellae 4-7, 7-9 cells high. Sex: unisexual. Spores: $10-14 \mu$ in diameter. Wisconsin, Minnesota south to Texas, Louisiana and Florida; Newfoundland, Nova Scotia, New Brunswick, Ontario; Europe and Asia. In addition to material collected in southern Michigan by the author, plants from Tennessee were also examined. Seven bivalents are regularly found at metaphase I (fig. 6-7). The gametophytic chromosome number is 7. The chromosomes of the complement may be divided into two groups, 4 long $(4-6.4 \mu)$ and 3 shorter (2.8-3.5 $\mu$ ), (fig. 5).

Atrichum xanthopelma (C. Müll.) Jaeg. A complete description of this species is unnecessary since it differs from the above only in the presence of papillae on the leaf cells. Maine to Minnesota and south to Missouri and Florida. In addition to plants from southern Michigan, a collection of this species from Florida was also examined. The chromosomes appear to be identical to those of Atrichum angustatum. 7 bivalents are regularly present at metaphase $I$ in the spore mother cells and 7 chromosomes are found in the gametophyte (fig. 8-10).

Atrichum undulatum (Hedw.) Beauv. The stem: up to $8 \mathrm{~cm}$. in height, rarely branched; Upper leaves: ligulate, $5-9 \mathrm{~mm}$. long, $1-1.3 \mathrm{~mm}$. wide; undulate; teeth on the back on the undulations; apex acute often cuspidate; margin serrate from the base or near the base to the apex; most of the teeth double; leaf cells $18-40 \mu$ in longest diameter; costa with its lamellae obscuring approximately $1 / 10$ of the median leaf width; lamellae $2-6,2-6$ cells high. Sex: bisexual. Spores: $9-23 \mu$ in diameter. Newfoundland to Alaska and south to California and Florida; Europe; Asia; Africa. In addition to plants from southern Michigan, collections from Tennessee and northern Michigan were ex- 
amined. All collections from southern Michigan and the collection from Tennessee proved to be diploid, 14 chromosomes are present at metaphase of mitosis in gametophyte tissue (fiig. 13). Meiosis was studied extensively in plants from southern Michigan and in all cases 14 bivalents were found at metaphase I (fig. 1-2, 14-15). The collection from northern Michigan proved to be haploid $(n=7)$ as determined from gametophytic squashes (fig. 11-12). The plants of this collection agree in morphological characteristics with the description of Atrichum undulatum except for the fact that they are unisexual.

Discussion. - Of the Atrichums studied in this work $A$. crispum is the most distinctive species morphologically. It is easily recognized by its oval to lanceolate-oblong leaves, the absence of teeth on the back of the lamina and relatively large leaf cells and weakly developed lamellae. Although the plant has a rather wide distribution in North America it is much less frequent throughout its range than the other species. The somatic chromosomes do not differ significantly from those of the other seven-chromosome species (table 1). This suggests that major structural alterations of the chromosomes have not occurred to any great extent in its evolution.

Atrichum angustatum and A. xanthopelma differ only in the occurrence of papillae on the leaf cells of the latter. The degree of papillosity is quite variable, in some collections many leaf cross sections must be examined to find a few cells with one or two papillae while other collections will show several cells with papilae in nearly every section. Cytologically the two plants are identical, each possessing a set of seven chromosomes in the gam-

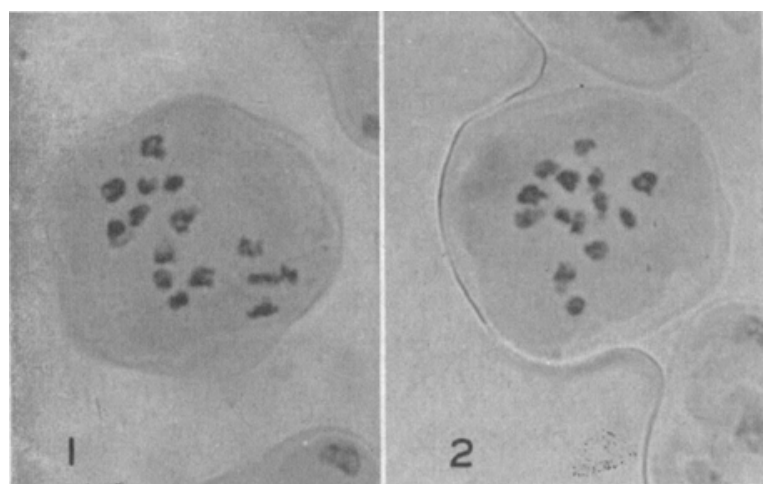

Fig. 1-2. Atrichum undulatum $n=14$. Spore mother cells showing 14 bivalents at metaphase I. 1000X.
TABLE I. Chromosome number and lengths.

\begin{tabular}{lccc}
\hline Species* & $\begin{array}{c}\text { Chromo- } \\
\text { some } \\
\text { number }\end{array}$ & $\begin{array}{c}\text { Average chromosome } \\
\text { length in microns }\end{array}$ \\
\hline Atrichum crispum & $n=7$ & $6.2,5.5,4.7,4.2,3.4,3,2.5$ \\
Atrichum angustatum & $n=7$ & $6.4,5, \quad 4.5,4,3.5,3.2,2.8$ \\
Atrichum xanthopelma & $n=7$ & $6.1,5,4.5,4.3,3.5,3,2.5$
\end{tabular}

"All three of the above species are unisexual.

etophyte. Allowing for errors in measurement, the chromosomes of the two sets are essentially similar in structure (table 1). In the spore mother cells both plants regularly form seven bivalents at metaphase I (fig. 6-7, 8-9). Considering both the morphological and cytological data, it appears to the author that the two plants are not sufficiently distinct to be considered separate species and as suggested by Frye, no violence would be done in considering $A$. xanthopelma a variety of $A$. angustatum.

The American $A$. angustatum does not differ in chromosome number from Japanese material reported by Kurita in 1937.

In the following table the average chromosome lengths of the above three species are recorded.

Atrichum undulatum has much the same range as $A$. angustatum but is a more robust plant of moister situations. It may be distinguished from $A$. angustatum by its larger ligulate leaves, larger leaf cells, the fact that the costa and lamellae obscure only about $1 / 10$ the leaf width and further that the plants are bisexual.

In 1926 Heitz reported the chromosome number of European material of this species as " $14-16$ " and in 1928 as " $(20-) 21(-22) . "$ In 1937 Kurita reported 21 chromosomes for Asiatic material. Wilson in 1911 reported a count of 16-17 for American material. All bisexual specimens examined in this study proved to have 14 chromosomes in the gametophyte and in the spore mother cells 14 bivalents were regularly formed at metaphase I (fig. 13-15). The 14 chromosomes of the gametophytic complement are easily sorted into 7 similar pairs, suggesting that the diploid condition arose as a result of simple doubling. The fact that the plant is bisexual also suggests that the chromosome doubling was the result of apsopory or an unreduced spore. I thought for a time that the most likely parent species from which $A$. undulatum could have arisen by chromosome doubling was $A$. angustatum for the following reasons: the

Fig. 3-15.-Fig. 3-4. Atrichum crispum $n=7$. Metaphase chromosomes in meristematic cells of the gametophyte. Fig. 5-7. A. angustatum.-Fig. 5. Metaphase chromosomes in a meristematic cell of the gametophyte.-Fig. 6-7. Spore mother cells showing 7 bivalents at metaphase I.-Fig. 8-10. A. xanthopelma.-Fig. 8-9. Spore mother cells showing 7 bivalents at metaphase I.-Fig. 10. Metaphase chromosomes in a meristematic cell of the gametophyte.-Fig. 11-12. A. undulatum $n=7$. Metaphase chromosomes in meristematic cells of the gametophyte-Fig. 13-15. A. undulatum $n=14$. Fig. 13. Metaphase chromosomes in a meristematic cell of the gametophyte.-Fig. 14-15. Spore mother cells showing 14 bivalents at metaphase I. All figures $2100 \times$. 


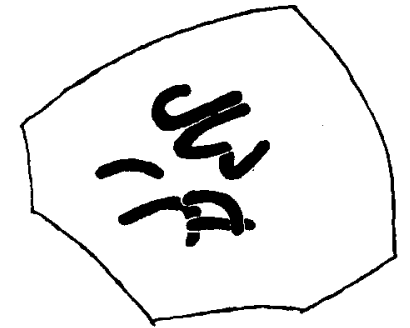

3
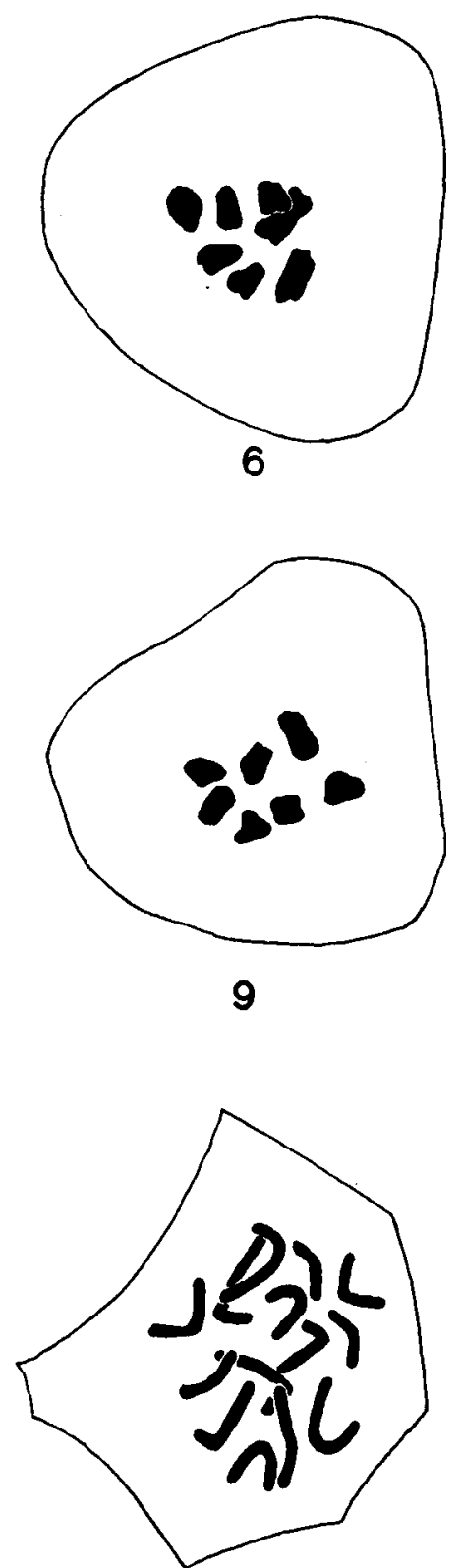

13

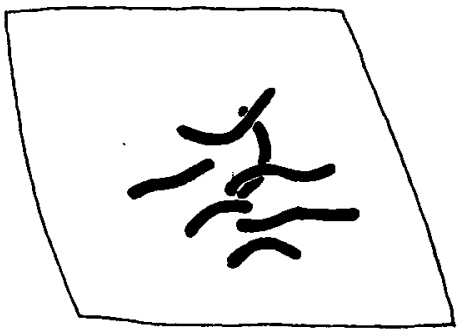

4
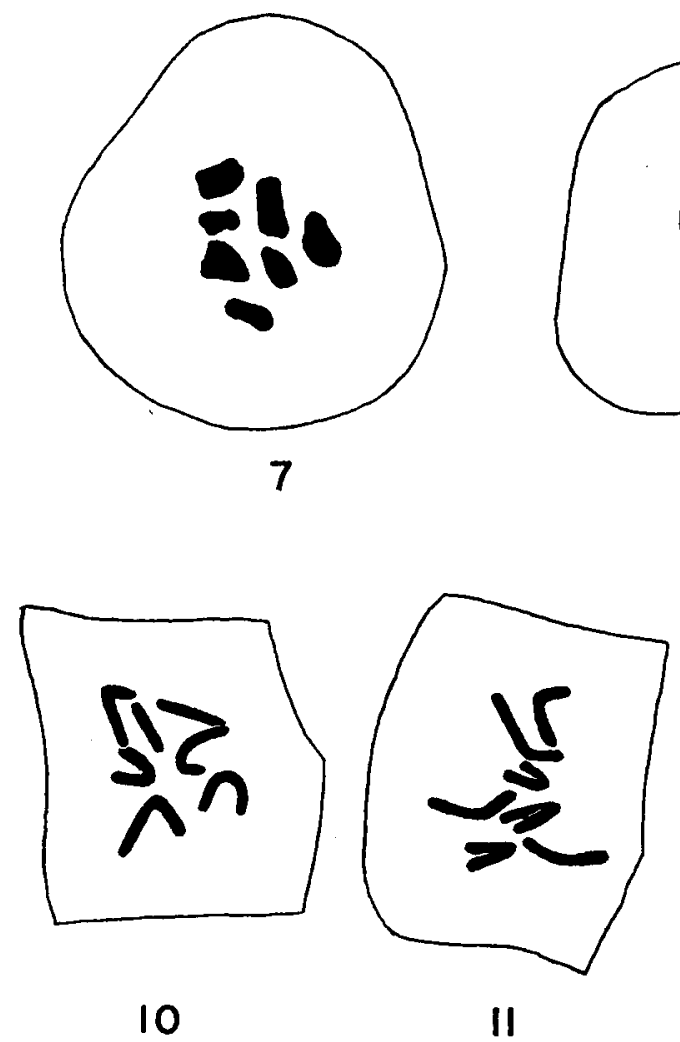

10

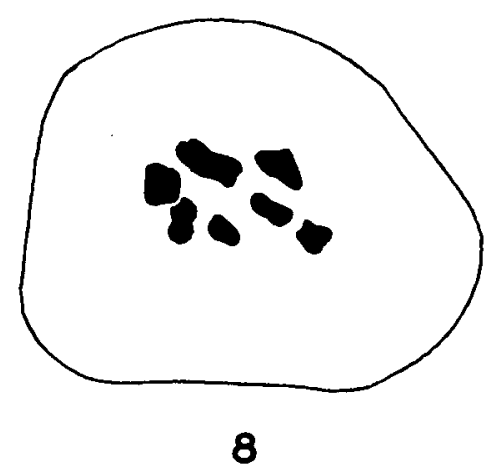

5
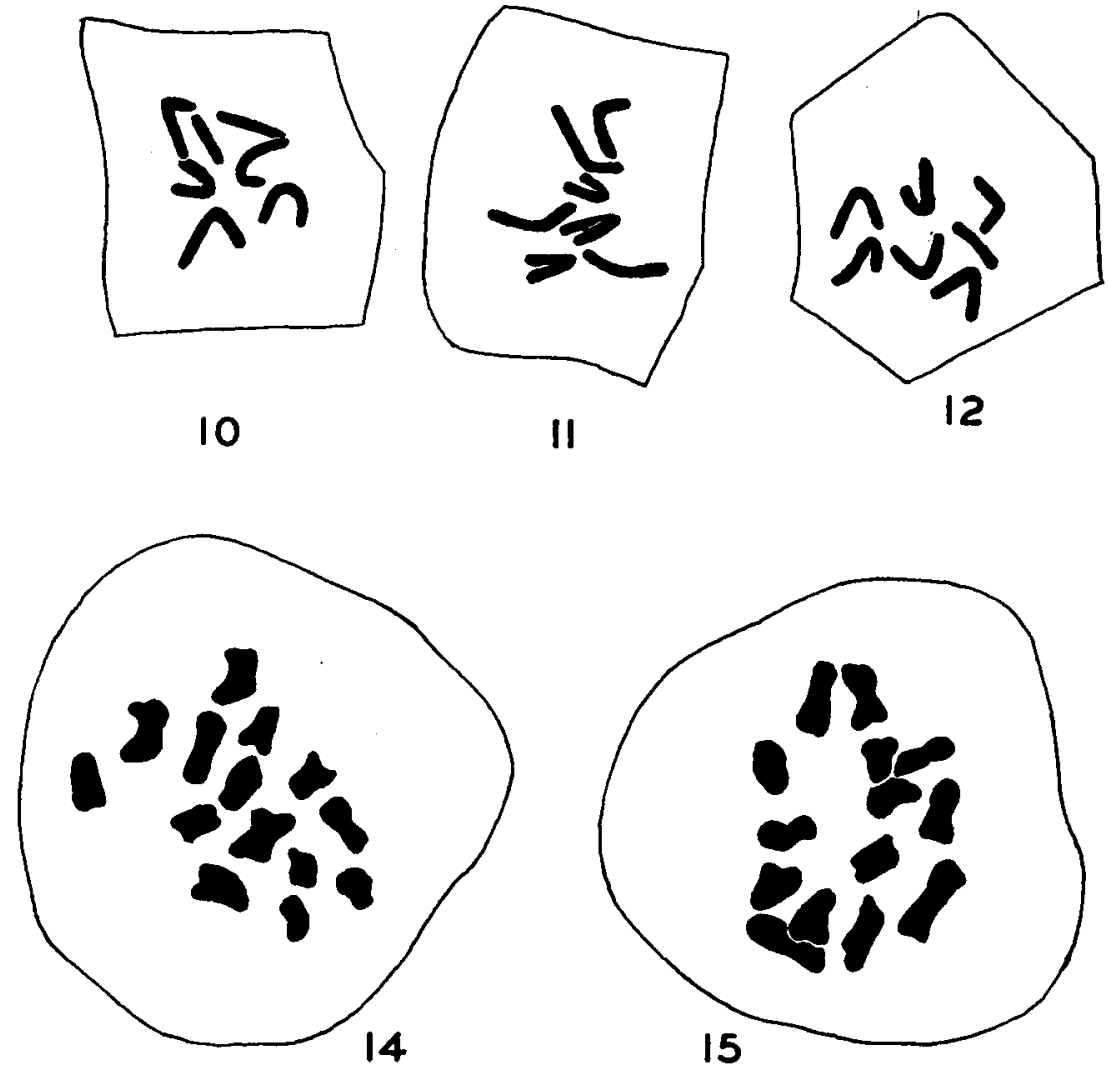
two species occur together throughout much of their range in North America; although the two species differ to some extent in habitat, they are occasionally found growing together; several of the morphological characteristics of the two differ in a quantitative fashion and the morphology of the gametophytic chromosomes of the two species is identical. However, to account for all of the morphological differences between them it seemed necessary to postulate a considerable differentiation in $A$. undulatum following chromosome doubling. The question of the ancestral form of $A$. undulatum was apparently resolved by the discovery of a 7 chromosome, dioicous race of the species in a collection from Au Train Falls in northern Michigan. In morphological characteristics other than sex, the plants of this collection do not differ significantly from typical $A$. undulatum and it thus seems quite reasonable to suppose that the diploid arose as a result of apospory from the 7 chromosome race. The chromosomes of the Au Train material do not differ significantly in length from the 14 pairs of the diploid, both complements being within the range of 3 to $6 \mu$ (fig. 11-12). Atrichum selwyni differs from $A$. undulatum only in the higher lamellae of the leaf and the dioecious sex condition. While material of this species was not available for cytological study, it seems reasonable to predict that its chromosome number is 7 due to the usual correlation between haploidy and unisexuality and diploidy and bisexuality in Mnium (Lowry, 1948) and in the Atrichums reported in this paper.

It is of interest to note that the haploid and diploid Atrichum undulatum reported here and the triploid European and Asiatic material of this species form the most extended natural intraspecific polyploid series known in the mosses.

Considering the morphological and cytological data the relationships between the species reported in this paper appear to be as follows. Through evolutionary processes other than polyploidy or structural changes in the chromosomes, three 7 . chromosome genetic entities were developed which are represented today by $A$. crispum, $A$. angustatum and $A$. undulatum $(n=7)$. From the latter the bisexual $A$. undulatum arose as the result of apospory. The triploid Asiatic and European $A$. undulatum could have been the result of hybridiza-

tion between the 7- and 14-chromosome races, followed by apospory. A. xanthopelma probably arose from $A$. angustatum as the result of gene mutation. The above concepts are illustrated in the following chart.

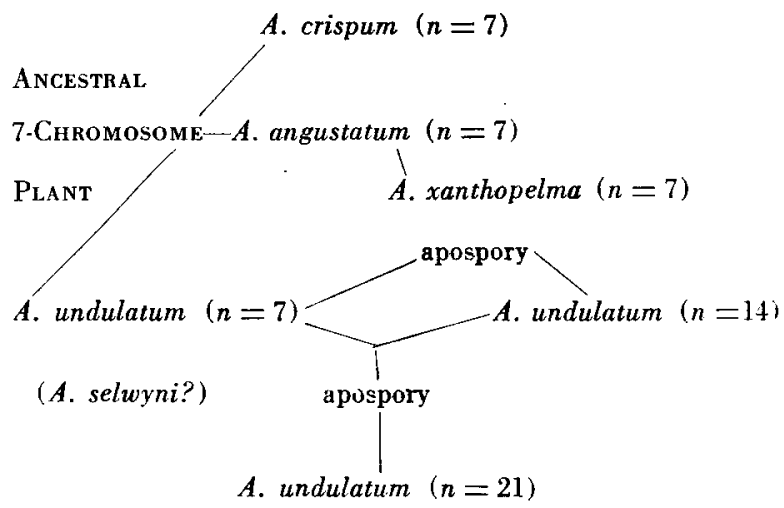

The basic chromosome number of the genus is 7. An inspection of previous chromosome counts within the Polytrichaceae indicates 7 as the basic chromosome number for the genera Polytrichum and Pogonatum (Lowry, 1948).

\section{SUMMARY}

The chromosome number of Atrichum crispum, A. angustatum, A. xanthopelma and $A$. undulatum was determined. $A$. undulatum was found to be diploid; however a dioicous, haploid collection of this species was discovered. No significant differences were found in the morphology of the chromosomes of the species studied. The basic chromosome number was found to be seven. Possible origin and relationships of the species are presented based on morphology and the cytological data. Evolutionary processes other than polyploidy and gross structural changes in the chromosomes have played the greatest role in the development of the species. Only Atrichum undulatum $(n=14)$ seems to have originated by apospory. Hybridization as a factor in the evolution of the genus is suggested by the occurrence of a 21 chromosome race of $A$. undulatum in Europe and Asia.

$$
\begin{aligned}
& \text { Department of Botany } \\
& \text { University of Michigan } \\
& \text { Ann Arbor, Michigan }
\end{aligned}
$$

\section{LITERATURE CITED}

Anderson, L. E. 1938. Some remarks on papillose forms in the genus Atrichum with a redescription of $A$. macmillani. Bryologist 41: 142-144.

FRYe, T. C. 1937. Polytrichaceae. In A. J. Grout. Moss Flora of North America 1: 99-128.

- 1949a. Atrichum xanthopelma. Bryologist 52: 191-194.

—. 1949b. Atrichum selwyni. Bryologist 52: 201.207.

HeITz, E. 1926. Der Nachweis der Chromosomen. Zeits. Bot. 18: 625 .
1928. Das Heterochromatin der Moose. Jahrb. Wiss. Bot. 69: 762-818.

Kurita, M. 1937. Geschlechtschromosomen und Chromosomenzahlen bei einigen Laubmoosen. Zeitschr. Indukt. Abstamm. Vererb. 74: 24-29.

Lowny, R. J. 1948. A cytotaxonomic study of the genus Mnium. Mem. Torrey Bot. Club 20(2) : I-42.

Schornherst, Ruth O. 1950. Atrichum in the Coastal Plain. Bryologist 53: 138.

WiLson, M. 1911. Spermatogenesis in the Bryophyta. Ann. Bot. 25: 4.15-457. 